\title{
High Prevalence of Haplorchis taichui, Phaneropsolus molenkampi, and Other Helminth Infections among People in Khammouane Province, Lao PDR
}

\author{
Jong-Yil Chai ${ }^{1, *}$, Eun-Taek Han', Eun-Hee Shin ${ }^{1,3}$, Woon-Mok Sohn", Tai-Soon Yong ${ }^{5}$, Keeseon S. Eom 6 , \\ Duk-Young Min ${ }^{7}$, Jin-Young Um ${ }^{8}$, Min-Sung Park ${ }^{8}$, Eui-Hyug Hoang ${ }^{8}$, Bounlay Phommasack', \\ Bounnaloth Insisiengmay ${ }^{9}$, Soon-Hyung Lee ${ }^{1,8}$ and Han-Jong Rim ${ }^{10}$ \\ 'Department of Parasitology and Tropical Medicine, Seoul National University College of Medicine, and Institute of Endemic Diseases, Seoul National \\ University Medical Research Center, Seoul 110-799, Korea; '2Department of Parasitology, College of Medicine, Kangwon National University, \\ Chuncheon 200-701, Korea; ${ }^{3}$ Seoul National University Bundang Hospital, Gyeonggi-do 463-707, Korea; ${ }^{4}$ Department of Parasitology and Institute of \\ Health Sciences, Gyeongsang National University School of Medicine, Jinju 660-751, Korea; '5epartment of Parasitology, College of Medicine, \\ Yonsei University, Seoul 120-752, Korea; ${ }^{6}$ Department of Parasitology, College of Medicine, Chungbuk National University, Chongju 361-763, Korea; \\ 'Department of Microbiology and Immunology, School of Medicine, Eulji University, Daejeon 301-746, Korea; ${ }^{8}$ Korea Association of Health Promotion, \\ Seoul 157-704, Korea; ${ }^{9}$ Department of Hygiene and Prevention, Ministry of Public Health, Vientiane, Lao PDR; ${ }^{10}$ Department of Parasitology, College \\ of Medicine, Korea University, Seoul 136-705, Korea
}

\begin{abstract}
The prevalence of liver and intestinal helminth infections, including Opisthorchis, Haplorchis, Phaneropsolus, hookworms, Enterobius, and Taenia, was surveyed in Khammouane province, Lao PDR. Fecal specimens were collected from 1,242 people (590 men and 652 women) in 3 Mekong riverside villages and were examined by the Kato-Katz thick smear technique. The overall helminth egg positive rate was $81.1 \%$. The positive rate for small trematode eggs, including Opisthorchis viverrini, heterophyids, and lecithodendriids, was $81.1 \%$ and the positive rate for hookworms was $6.7 \%$. To obtain adult worms, 35 people who were positive for small trematode eggs were treated with $20-30 \mathrm{mg} / \mathrm{kg}$ praziquantel and $10-15 \mathrm{mg} / \mathrm{kg}$ pyrantel pamoate, and then purged. Diarrheic stools were collected from 33 of these people and searched for helminth parasites using a stereomicroscope. Mixed infections with various helminths (Haplorchis taichui, Haplorchis yokogawai, Prosthodendrium molenkampi, Phaneropsolus bonnei, echinostomes, hookworms, Trichostrongylus spp., Trichuris trichiura, Enterobius vermicularis, and/or Taenia saginata) were found. The total number of helminth specimens collected was 20,907 (approximately 634 per person). The most common species was $H$. taichui, followed by $P$. molenkampi, $O$. viverrini, P. bonnei, E. vermicularis, hookworms, and Trichostrongylus spp. These results show that diverse species of intestinal nematodes, trematodes, and cestodes are infecting humans in Khammouane province, Lao PDR.
\end{abstract}

Key words: Opisthorchis viverrini, Haplorchis taichui, Haplorchis yokogawai, Prosthodendrium molenkampi, Phaneropsolus bonnei, hookworm, Trichostrongylus, Taenia saginata, prevalence, Khammouane province, Laos

\section{INTRODUCTION}

Soil-transmitted and fecal-borne nematodes, and food-borne liver and intestinal trematodes and cestodes, are important parasites from public health points of view [1-3]. These parasites include Ascaris, hookworms, Enterobius, Opisthorchis, Clonorchis, echinostomes, heterophyids (Heterophyes, Metagonimus, Haplorchis, and Centrocestus), lecithodendriids (Prosthodendrium and Phaneropsolus), Diphyllobothrium, and Taenia [3-5]. To prevent and control these parasites, epidemiological studies are urgent and pre-requisite.

- Received 2 June 2009, revised 30 July 2009, accepted 3 August 2009.

* Corresponding author (cjy@snu.ac.kr)
In Lao PDR, which is located in the middle of the Indochina Peninsula, the Mekong River runs through the whole length of the country from north to south. Until the 1990s, the liver fluke, Opisthorchis viverrini, and soil-transmitted nematodes, including Ascaris lumbricoides, Trichuris trichiura, and hookworms (Ancylostoma duodenale and Necator americanus), were the major helminth species known to be infecting Laotians [6-9]. However, in 1991, Haplorchis taichui worms were recovered from 5 Laotian students studying in Czechoslovakia [10]. Since then, mixed infections with O. viverrini, H. taichui, Haplorchis pumilio, Haplorchis yokogawai, Centrocestus formosanus (as C. caninus), Prosthodendrium molenkampi, Phaneropsolus bonnei, Echinochasmus japonicus, and other echinostomes have been recovered from residents of Vientiane Municipality, Saravane province, and Savan- 
nakhet province [11-13]. In addition to these helminths, Sayasone et al. [13] also recovered Taenia saginata tapeworms. Interestingly, the intensity of infection of each parasite species varied with the locality surveyed. For example, in Vientiane Municipality, O. viverrini infection was dominant, whereas in Saravane province H. taichui infection was dominant [11].

Intestinal nematode recovery data after anthelmintic treatment and purgation has never been reported in Lao PDR. Therefore, the present study aimed to determine the infection status of foodborne intestinal trematodes and cestodes, including O. viverrini, H. taichui, and Taenia species, and soil-transmitted nematodes, including hookworms and Trichostrongylus, among the riverside residents of Khammouane province.

\section{MATERIALS AND METHODS}

Khammouane province, Lao PDR, is located about $300 \mathrm{~km}$ distance from Vientiane Municipality and about $120 \mathrm{~km}$ north of Savannakhet province (Fig. 1). Three small riverside villages (Bane Nong Bone, Bane Mahaxay, and Bane Phova) located near tributaries of the Mekong River were selected for this study. Most residents are agricultural workers. Some catch freshwater fish and aquatic insect larvae from small streams and ponds, and

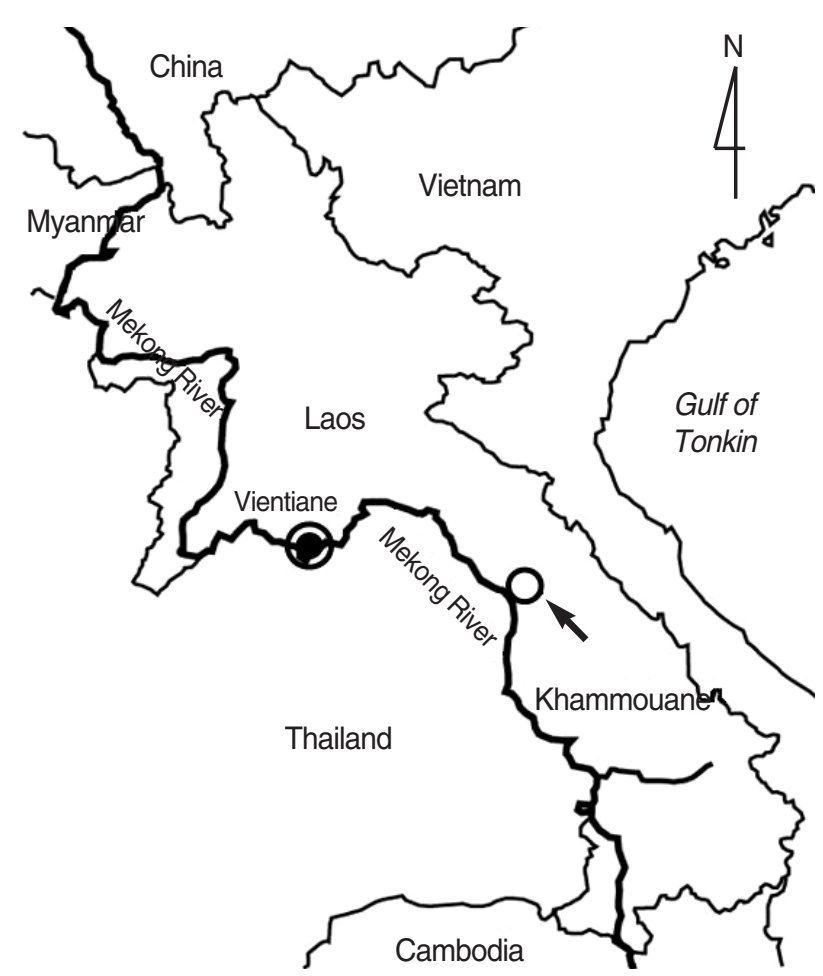

Fig. 1. Map showing the surveyed area of Lao PDR (arrow: Khammouane). consume them improperly cooked.

A total of 1,242 fecal samples, one sample from each person, were collected from residents (590 men and 652 women; aged 6-80 years) of the 3 villages, in March 2003. Samples were transported to the Malaria Station in Khammouane within 2-3 days of collection and were stored at $4^{\circ} \mathrm{C}$ until examined. The KatoKatz thick smear technique was used to detect helminth eggs. As it was not possible to differentiate eggs of $O$. viverrini from those of heterophyids and lecithodendriids, these eggs were collectively recorded as small trematode eggs. Fecal examinations of these residents and anthelmintic treatments were officially approved by the Ministry of Public Health, Laos, under the terms of the Korea-Laos Agreement on Parasite Control in Laos (19992004).

A total of 35 people who tested positive for small trematode eggs were selected for adult worm recovery at the Malaria Station. After obtaining informed consent, they were treated with a mixed single dose of $20-30 \mathrm{mg} / \mathrm{kg}$ praziquantel (Distocide ${ }^{\circledR}$, Shinpoong Pharm. Co., Seoul, Republic of Korea) and 10-15 $\mathrm{mg} / \mathrm{kg}$ of pyrantel pamoate (Combantrin ${ }^{\circledR}$, Pfizer, New York, USA), and then purged with magnesium salt. Whole diarrheic stools passed successively $4-5$ times were collected from 33 people. Worms were collected using a glass pipette and were washed several times in water. Worms were counted and some were fixed with $10 \%$ formalin under cover slip pressure, acetocarminestained, and morphologically identified using a light microscope.

Fecal examination results were analyzed with respect to age and sex of the subjects using the Student's $t$-test and the chi-

Table 1. Helminth eggs found in the feces of residents in Khammouane province, Laos (March 2003)

\begin{tabular}{|c|c|c|c|}
\hline \multirow{2}{*}{ Helminth species } & \multicolumn{3}{|c|}{ No. of residents (\%) } \\
\hline & Men & Women & Total \\
\hline No. examined ${ }^{a}$ & 590 & 652 & 1,242 \\
\hline $\begin{array}{l}\text { No. helminth egg positive } \\
\text { cases (\%) }\end{array}$ & $490(83.1)$ & $517(79.3)$ & $1,007(81.1)$ \\
\hline Ascaris lumbricoides & $5(0.8)$ & $5(0.8)$ & $10(0.8)$ \\
\hline Hookworms & 49 (8.3) & $34(5.2)$ & $83(6.7)$ \\
\hline Trichuris trichiura & $39(6.6)$ & $36 \quad(5.5)$ & $75(6.0)$ \\
\hline Trichostrongylus spp. & $1(0.2)$ & $0(0.0)$ & $1(0.08)$ \\
\hline $\begin{array}{l}\text { Opisthorchis viverrini and } \\
\text { small trematode eggs }^{b}\end{array}$ & $499(84.6)$ & $508(77.9)$ & $1,007(81.1)$ \\
\hline Echinostomes & $3(0.5)$ & $4(0.6)$ & $7(0.6)$ \\
\hline Fasciolopsis buski & $0(0.0)$ & $2(0.3)$ & $2(0.2)$ \\
\hline Taenia spp. & $27(4.6)$ & $31(4.8)$ & $58(4.7)$ \\
\hline
\end{tabular}


square test. $P$-values of $<0.05$ were considered statistically significant.

\section{RESULTS}

\section{Fecal examination}

The overall helminth egg positive rate was $81.1 \%$ (Table 1), and there were mixed infections involving different kinds of trematodes and nematodes. The most frequently encountered were small trematode eggs, including those of $O$. viverrini, heterophyids, and lecithodendriids. The positive rate of small trematode eggs was $81.1 \%$ (Table 1 ). Other parasite eggs detected were hookworms (6.7\%), Trichuris trichiura (6.0\%), Taenia spp. (4.7 $\%)$, Ascaris lumbricoides (0.8\%), echinostomes (0.6\%), Fasciolopsis buski (0.2\%), and Trichostrongylus spp. (0.08\%). The egg positive rates were not significantly $(P>0.01)$ different between men

Table 2. Adult flukes colleced from residents in Khammouane province, Laos, after treatment with praziquantel and pyrantel pamoate (March 2003)

\begin{tabular}{|c|c|c|c|c|c|c|c|c|c|c|c|c|}
\hline \multirow{2}{*}{$\begin{array}{l}\text { Age and } \\
\text { sex of } \\
\text { resident }\end{array}$} & \multicolumn{12}{|c|}{ No. of helminth specimens collecteda } \\
\hline & $\begin{array}{l}\text { O. viver- } \\
\text { rini }\end{array}$ & $\begin{array}{c}H . \\
\text { taichui }\end{array}$ & $\begin{array}{c}\text { H. yoko- } \\
\text { gawai }\end{array}$ & $\begin{array}{l}\text { P. molen- } \\
\text { kampi }\end{array}$ & $\begin{array}{c}P . \\
\text { bonnei }\end{array}$ & $\begin{array}{l}\text { Echino } \\
\text { stomes }^{\text {b }}\end{array}$ & $\begin{array}{l}\text { Hook- } \\
\text { worms }^{b}\end{array}$ & $\begin{array}{c}T . \\
\text { trichiura }\end{array}$ & $\begin{array}{l}\text { Trichostron- } \\
\text { gylus spp. }\end{array}$ & $\begin{array}{l}\text { E. vermi- } \\
\text { cularis }\end{array}$ & Taenia $^{\mathrm{C}}$ & Total \\
\hline $80 \mathrm{M}$ & 2 & 469 & 8 & 1 & 0 & 0 & 1 & 0 & 0 & 1 & 0 & 482 \\
\hline $65 \mathrm{M}$ & 1 & 96 & 13 & 7 & 2 & 0 & 0 & 0 & 1 & 8 & 1 & 129 \\
\hline $61 \mathrm{M}$ & 21 & 23 & 0 & 0 & 53 & 0 & 0 & 0 & 1 & 13 & 0 & 111 \\
\hline $60 \mathrm{~F}$ & 19 & 115 & 0 & 5 & 1 & 0 & 0 & 0 & 0 & 6 & 0 & 146 \\
\hline $59 \mathrm{M}$ & 0 & 222 & 0 & 10 & 0 & 0 & 0 & 0 & 0 & 27 & 0 & 259 \\
\hline $58 \mathrm{M}$ & 27 & 208 & 0 & 69 & 0 & 0 & 0 & 0 & 0 & 4 & 0 & 308 \\
\hline $56 \mathrm{M}$ & 41 & 241 & 0 & 2 & 0 & 0 & 0 & 0 & 2 & 0 & 1 & 287 \\
\hline $55 \mathrm{M}$ & 0 & 204 & 0 & 0 & 4 & 0 & 0 & 0 & 0 & 2 & 1 & 211 \\
\hline $50 \mathrm{M}$ & 4 & 399 & 0 & 76 & 145 & 0 & 0 & 0 & 1 & 11 & 0 & 636 \\
\hline $50 F$ & 0 & 7 & 0 & 0 & 0 & 0 & 0 & 0 & 0 & 0 & 0 & 7 \\
\hline $48 \mathrm{M}$ & 205 & 110 & 0 & 256 & 29 & 3 & 3 & 1 & 0 & 1 & 0 & 608 \\
\hline $43 \mathrm{M}$ & 1 & 36 & 0 & 6 & 47 & 1 & 8 & 0 & 0 & 6 & 1 & 106 \\
\hline $42 \mathrm{M}$ & 7 & 730 & 0 & 96 & 0 & 4 & 0 & 0 & 0 & 0 & 0 & 837 \\
\hline $42 \mathrm{~F}$ & 26 & 197 & 0 & 190 & 48 & 25 & 1 & 0 & 0 & 1 & 1 & 489 \\
\hline $41 F$ & 22 & 479 & 0 & 0 & 0 & 0 & 0 & 0 & 0 & 1 & 1 & 503 \\
\hline $40 M$ & 11 & 102 & 0 & 3,967 & 129 & 0 & 8 & 0 & 0 & 1 & 0 & 4,218 \\
\hline $40 F$ & 51 & 111 & 0 & 304 & 5 & 1 & 0 & 0 & 7 & 7 & 1 & 487 \\
\hline $37 \mathrm{M}$ & 23 & 0 & 0 & 0 & 0 & 0 & 0 & 0 & 0 & 0 & 0 & 23 \\
\hline $35 F$ & 12 & 13 & 17 & 9 & 5 & 0 & 1 & 0 & 2 & 3 & 0 & 62 \\
\hline $34 \mathrm{M}$ & 0 & 137 & 0 & 40 & 125 & 1 & 0 & 0 & 6 & 0 & 1 & 310 \\
\hline $32 \mathrm{M}$ & 41 & 32 & 0 & 42 & 9 & 2 & 2 & 0 & 1 & 12 & 0 & 141 \\
\hline $32 \mathrm{~F}$ & 369 & 2,246 & 0 & 5 & 3 & 0 & 12 & 0 & 0 & 20 & 0 & 2,655 \\
\hline $30 F$ & 68 & 28 & 0 & 6 & 197 & 14 & 0 & 0 & 0 & 2 & 2 & 317 \\
\hline $28 \mathrm{M}$ & 94 & 11 & 0 & 4 & 1 & 0 & 34 & 0 & 0 & 0 & 2 & 146 \\
\hline $25 \mathrm{M}$ & 4 & 3,045 & 0 & 2 & 31 & 1 & 2 & 0 & 0 & 5 & 0 & 3,090 \\
\hline $23 \mathrm{M}$ & 60 & 144 & 0 & 2,225 & 58 & 0 & 2 & 0 & 35 & 14 & 2 & 2,540 \\
\hline $18 \mathrm{M}$ & 46 & 136 & 0 & 162 & 16 & 0 & 4 & 0 & 0 & 0 & 1 & 365 \\
\hline $17 \mathrm{M}$ & 49 & 170 & 0 & 6 & 0 & 0 & 1 & 0 & 0 & 24 & 0 & 250 \\
\hline $16 \mathrm{M}$ & 0 & 770 & 0 & 0 & 0 & 0 & 1 & 0 & 0 & 0 & 0 & 771 \\
\hline $16 F$ & 132 & 116 & 0 & 4 & 2 & 0 & 1 & 0 & 0 & 5 & 0 & 260 \\
\hline $13 \mathrm{M}$ & 0 & 32 & 0 & 6 & 0 & 0 & 2 & 0 & 0 & 0 & 0 & 40 \\
\hline $9 \mathrm{M}$ & 21 & 62 & 0 & 10 & 0 & 0 & 0 & 0 & 0 & 0 & 0 & 93 \\
\hline $6 \mathrm{M}$ & 20 & 0 & 0 & 0 & 0 & 0 & 0 & 0 & 0 & 0 & 0 & 20 \\
\hline $\begin{array}{l}\text { Total } \\
\text { (Mean No./ } \\
\text { person) }\end{array}$ & $\begin{array}{r}1,377 \\
(50)\end{array}$ & $\begin{array}{r}10,691 \\
(324)\end{array}$ & $\begin{array}{l}38 \\
(1)\end{array}$ & $\begin{array}{l}7,510 \\
(228)\end{array}$ & $\begin{array}{l}910 \\
(28)\end{array}$ & $\begin{array}{l}52 \\
(2)\end{array}$ & $\begin{array}{l}83 \\
(3)\end{array}$ & $\begin{array}{r}1 \\
(0.03)\end{array}$ & $\begin{array}{l}56 \\
(2)\end{array}$ & $\begin{array}{r}174 \\
(5)\end{array}$ & $\begin{array}{l}15 \\
(1)\end{array}$ & $\begin{array}{r}20,907 \\
(634)\end{array}$ \\
\hline
\end{tabular}

${ }^{a}$ O. viverrini, Opisthorchis viverrini; H. taichui, Haplorchis taichui; H. yokogawai, Haplorchis yokogawai; P. molenkampi, Prosthodendrium molenkampi; P. bonnei, Phaneropsolus bonnei; T. trichiura, Trichuris trichiura; E. vermicularis, Enterobius vermicularis; ${ }^{\text {bS} S p e c i e s ~ n o t ~ d e t e r m i n e d ; ~}{ }^{\circ} T$ he whole or a part of strobilae with or without a scolex were recovered. All were morphologically identified as Taenia saginata. 
and women (Table 1), or between different age groups (data not shown).

\section{Worm collection}

The adult worm collection was completed in 33 people ( 24 men and 9 women; age range 6-80 years) (Table 2) and a total of 20,907 helminth specimens were recovered. Between 7 and 4,218 were collected per person, with an average of 634. Intestinal flukes were recovered from 31 cases (93.9\%), and O. viverrini was from 27 cases (81.8\%). The numbers of trematode specimens were 10,691 H. taichui, 7,510 P. molenkampi, 1,377 O. viverrini, 910 P. bonnei, 52 echinostomes (species to be determined), and 38 H. yokogawai (Table 2). Intestinal trematodes, including Haplorchis, lecithodendriids, and echinostomes, comprised $91.8 \%$ of all helminth specimens recovered, whereas $O$. viverrini and intestinal nematodes comprised only $6.6 \%$ and 1.5 $\%$, respectively (Table 2 ).

The highest worm load of $H$. taichui collected from a single person was 3,045, and the average number of $H$. taichui recovered per treated person was 324. Specimens of $H$. yokogawai were collected only from 3 persons. As for lecithodendriids, the number of $P$. molenkampi worms ranged from 0 to 3,967 (av. 228 worms per person), and the number of $P$. bonnei ranged from 0 to 197 (av. 28 worms per person). Data on echinostomes will be published separately.

The number of nematode and cestode specimens was $174 \mathrm{E}$. vermicularis, 83 hookworms (A. duodenale and N. americanus), 56 Trichostronglylus spp., 1 T. trichiura, and 15 strobilae of T. saginata (Table 2). With regard to E. vermicularis, the worms were collected from 22 of 33 treated persons and the worm load averaged 5 worms (mostly females) per treated person. The worm load was higher among 17-32 and 59-65 year age groups. Hookworms were collected from 16 of 33 treated persons, averaged 3 worms per treated person, and consisted of A. duodenale and N. americanus in a $1: 1$ ratio. Trichostrongylus spp. specimens consisted of male and female worms (about $0.8: 1$ ), and were recovered from a total of 9 persons (Table 2).

\section{DISCUSSION}

Our results suggested that most of the people who were positive for small trematode eggs had mixed-infections with several species of intestinal flukes, including heterophyids and lecithodendriids, and the liver fluke, O. viverrini. Fecal examinations to detect helminth eggs have considerable limitations for under- standing the prevalence and intensity of liver and intestinal flukes in Lao PDR, which was already known in the Republic of Korea [3] and Thailand [14,15]. In Lao PDR, this kind of limitation was reported in Vientiane Municipality and Saravane province [11] and also in Savannakhet province [12].

The relative prevalence of each fluke species varied remarkably by locality surveyed. For example, in Savannakhet and Vientiane, O. viverrini comprised up to $43.5 \%$ and $62.9 \%$ of all fluke specimens recovered, whereas in Saravane, intestinal flukes accounted for over $99.0 \%$ of all recovered flukes $[11,12]$. By comparison, in a recent study performed in Vientiane, Savannakhet, and Saravane, the worm loads of O. viverrini (av. 186 worms per worm-positive patient) and H. taichui (av. 207 worms) were quite similar in an analysis of 97 worm-recovered cases [13]. In our study, intestinal fluke infections predominated in Khammouane, although the degree of predominance $(91.8 \%)$ was a little less than in Saravane [11].

There is a possibility that not all of the flukes (in particular, O. viverrini) were collected from the praziquantel treated and purged patients, since the diarrheic stools were collected only 4-5 times (for 5-6 hr) [11,12] or 6-8 times (for $24 \mathrm{hr}$ ) [13] after praziquantel administration. It may take longer for all $O$. viverrini to be expelled from the bile duct and gall bladder into the stools. However, data can be compared between surveyed areas, if the same protocol was applied. Thus, the individual worm loads of $O$. viverrini could be compared between different provinces. In Savannakhet province, the number of expelled worms averaged 115 worms per treated person [12], followed by an average of 58 worms in Vientiane Municipality and an average of 22 worms in Saravane province [11]. In our study, an average of 50 worms was recovered in Khammouane, which is quite similar to Vientiane [11].

The average worm load of $H$. taichui per treated person was remarkably high $(8,514)$ in Saravane [11] compared to Khammouane (324; this study), Savannakhet (103) [12], and Vientiane (27) [11]. The highest worm load of lecithodendriid flukes was found in Khammouane (an average of 228 for P. molenkampi and an average of 28 for P. bonnei; this study), followed by Savannakhet (an average of 61 and 1, respectively) [12], Saravane (an average of 25 and 20, respectively), and Vientiane (an average of 3 and 0 , respectively) [11]. These results suggest that the relative predominance of trematode species varies greatly by locality in Lao PDR.

It is of note that a total of 4 nematode species and a cestode species were recovered from the residents of Khammouane. The 
higher worm loads of $E$. vermicularis among the persons at the ages of 17-32 and 59-65 year could be explained as that these people may have more contact with children, since they may have young children or grand children. Despite the relatively low prevalence of hookworm eggs (6.7\%), hookworm specimens were collected from 16 of 33 treated persons. This may indicate that the actual prevalence of hookworms may be higher than the egg positive rate. Only 1 specimen of $T$. trichiura was recovered, which seems to have been due to the negligible efficacy of pyrantel pamoate and praziquantel against this nematode. A least expected result, because of a low egg positive rate (0.08\%) in the fecal examination, was that a total of 56 specimens of Trichostrongylus spp. were recovered from 9 persons. A specimen collected from a Laotian was identified morphologically as $T$. colubriformis and its ITS-1 sequence was most similar to that of T. colubriformis [16]. However, the presence of T. orientalis, a common species in Asian countries [17], should not be ruled out in Lao PDR. The egg positive rate of Taenia spp. was 4.7\%, but 12 of 33 treated persons expelled Taenia tapeworms after praziquantel treatment, which suggests a considerably higher prevalence of this tapeworm infection in this area.

\section{ACKNOWLEDGEMENTS}

We thank Dr. Sithat Insisiengmay and the staff of the Center for Laboratory and Epidemiology, Department of Hygiene and Prevention, Ministry of Public Health, Vientiane, and the staff of the Khammouane Provincial Health Department, Khammouane, Lao PDR, for their help during the collection of fecal samples and for the preparation of Kato-Katz smears. We also thank the staff of the Korea Association of Health Promotion, Seoul, Republic of Korea, who participated in the Korea-Laos Cooperation Project on Parasite Control in Lao PDR (1999-2004). This study was supported by BK21 Human Life Sciences, Ministry of Education, Republic of Korea.

\section{REFERENCES}

1. World health Organization. Controlling Disease Due to Helminth Infections (eds. Crompton DWT et al.). Geneva, Switzerland. World Health Organization. 2003, p 1-248.

2. Chai JY, Murrell KD, Lymbry A. Fishborne parasitic zoonoses: status and issues. Int J Parasitol 2005; 35: 1233-1254.

3. Chai $J$, Lee SH. Food-borne intestinal trematode infections in the Republic of Korea. Parasitol Int 2002; 51: 129-154.
4. Shin EH, Guk SM, Lee SH, Chai JY. Trends in parasitic diseases in the Republic of Korea. Trends Parasitol 2008; 24: 143-150.

5. Jeon HK, Kim KH, Chai JY, Yang HJ, Rim HJ, Eom KS. Sympatric distribution of three human Taenia tapeworms collected between 1935 and 2005 in Korea. Korean J Parasitol 2008; 46: 235-241.

6. Sornmani S, Pathammavong O, Bunnag T, Impand P, Intarakhao C, Thirachantra S. An epidemiological survey of human intestinal parasites in Vientiane, Laos. Southeast Asian J Trop Med Public Health 1974; 5: 541-546.

7. Kobayashi J, Vannachone B, Xeutvongsa A, Manivong K, Ogawa S, Sato Y, Pholsena K. Prevalence of intestinal parasitic infection among children in two villages in Lao PDR. Southeast Asian J Trop Med Public Health 1996; 27: 562-565.

8. Chai JY, Hongvanthong B. A small-scale survey of intestinal helminthic infections among the residents near Pakse, Laos. Korean J Parasitol 1998; 36: 55-58.

9. Rim HJ, Chai JY, Min DY, Cho SY, Eom KS, Hong SJ, Sohn WM, Yong TS, Deodato G, Standgaard H, Phommasack B, Yun CY, Hoang EH. Prevalence of intestinal parasite infections on a national scale among primary schoolchildren in Laos. Parasitol Res 2003; 91: 267-272.

10. Giboda M, Ditrich O, Scholz T, Viengsay T, Bouaphanh S. Human Opisthorchis and Haplorchis infections in Laos. Trans R Soc Trop Med Hyg 1991; 85: 538-540.

11. Chai JY, Park JH, Han ET, Guk SM, Shin EH, Lin A, Kim JL, Sohn WM, Yong TS, Eom KS, Min DY, Hwang EH, Phommasack B, Insisiengmai B, Rim HJ. Mixed infections with Opisthorchis viverrini and intestinal flukes in residents of Vientiane Municipality and Saravane Province in Laos. J Helminthol 2005; 79: 283-289.

12. Chai JY, Han ET, Guk SM, Shin EH, Sohn WM, Yong TS, Eom KS, Lee KH, Jeong HG, Ryang YS, Hoang EH, Phommasack B, Insisiengmai B, Lee SH, Rim HJ. High prevalence of liver and intestinal fluke infections among residents of Savannakhet Province in Laos. Korean J Parasitol 2007; 45: 213-218.

13. Sayasone S, Vonghajack Y, Vanmany M, Rasphone O, Tesana S, Utzinger J, Akkhavong K, Odermatt P. Diversity of human intestinal helminthiasis in Lao PDR. Trans R Soc Trop Med Hyg 2009; 103: 247-254.

14. Manning GS, Lertprasert P, Watanasirmkit K, Chetty C. A description of newly discovered intestinal parasites endemic to northeastern Thailand. J Med Ass Thailand 1971; 54: 466-474.

15. Radomyos P, Radomyos B, Tungtrongchitr A. Multi-infection with helminths in adults from northeast Thailand as determined by post-treatment fecal examination of adult worms. Trop Med Parasitol 1994; 45: 133-135.

16. Yong TS, Lee JH, Sim SB, Lee JW, Min DY, Chai JY, Eom KS, Sohn WM, Lee SH, Rim HJ. Differential diagnosis of Trichostrongylus and hookworms eggs via PCR using ITS-1 sequence. Korean J Parasitol 2007; 45: 69-74.

17. John DT, Petri WA Jr. Markell and Voge's Medical Parasitology. 9th ed. St. Louis, Missouri, USA. Saunders Elsevier. 2006, p 266. 
